\title{
Diagnosis and damage of bearings
}

Marek Krynke, Jacek Selejdak, Stanisław Borkowski

Faculty of Management of Czestochowa University of Technology, Armii Krajowej 19b, 42-200 Częstochowa, e-mail: krynke@zim.pcz.pl

The article describes typical damage of rolling bearings and basic methods of their detection. From various methods of working bearings diagnosis the vibration method selected. Vibration signal contains a series of important technical information about the machine condition and is currently the most frequently used in diagnostic bearings systems. Furthermore, structure of vibroacoustic signal the frequency generated by the damaged bearing depends on the causes of the damage, the phases of its development and in particular the size of signals from other kinematic nodes, load, service quality and environmental impact. Monitoring the dynamic state of bearings nodes can carry out repairs technical conditioned by state of machines and omission preventive repairs conditioned by time and emergency repairs. In addition, the article describes the classification of bearing damage according to ISO standards, which identified the mechanisms related to the formation of any type of damage.

Keywords: rolling bearings, Vibration diagnostics.

\section{References}

[1] CEMPEL, C.: Decomposition of symptom observation matrix and its optimization in vibration condition monitoring of machines. Applied Mechanics and Materials, Volume 9, 2008, Pages 51-60.

[2] SWȨDROWSKI L.: Current measurements and analysis for induction motor diagnostics. Metrology and Measurement Systems. Volume 17, Issue 1, 2010.

[3] ŻÓŁTOWSKI B.: Podstawy diagnostyki maszyn, Wydawnictwo Uczelniane ATR, Bydgoszcz 1996 r.

[4] MAYER K., PEXA M., PAVLŮ J.: Impact of technical diagnostics interval on machinery maintenance. Manufacturing Technology (12), 2012, p. 42-46.

[5] KRZEMIŃSKI-FREDA, H., WARDA, B.: The effect of roller end-flange contact shape upon frictional losses and axial load of the radial cylindrical roller bearing. Tribology Series, Volume 14, Issue C, 1989, Pages $287-$ 295.

[6] PORADNIK CX Bearings: http://e-katalog.home.pl/CX_BEARINGS/poradnik.php?gr=5\&pod=17\&sub=1.

[7] MAZANEK E., KRYNKE M.: Uszkodzenia bieżni łożysk wieńcowych. Tribologia. Teoria i praktyka. Oficyna Wydawnicza SIMP. 3/2011 (37). Warszawa 2011. s.67-80.

[8] KANIA L., KRYNKE M., MAZANEK E.: Analiza przyczyn uszkodzeń bieżni łożysk wieńcowych podczas eksploatacji. XXIII Sympozjon PKM, Rzeszów - Przemyśl 2007, tom III: 62-71.

[9] WEINFURTNER L., PEXA M., MAYER K.: Stanovení životnosti ložisek na vibrodiagnostickém modelu. Manufacturing Technology (6), 2011, p. 52-59.

[10] KANIA L., KRYNKE M., MAZANEK E.: A Catalogue Capacity of Slewing Bearings. Mechanism and Machine Theory Vol.58. 2012. s.29-45.

[11] KANIA L.: Modelling of rollers in slewing bearing calculations with the use of finite elements. Mechanism and Machine Theory, 41 (2006), 11: 1359-1376.

[12] KRYNKE M., KANIA L., MAZANEK E: Modelling the contact between the rolling elements and the raceways of bulky slewing bearings. Key Engineering Materials, Vol. 490 2012. s.166-178.

[13] Uszkodzenia łożysk i ich przyczyny. Przegląd Mechaniczny nr 11/11.

[14] SZYMANIEC S.: Assessment of the condition of rolling bearings in electric motors. Archives of Electrical Engineering. Volume 56, Issue 221-222, 2007, Pages 299-316.

[15] Norma PN-90 N-01358, Metody pomiarów i oceny drgań maszyn.

[16] MAKOWSKI R, ZIMROZ R.: A procedure for weighted summation of the derivatives of reflection coefficients in adaptive Schur filter with application to fault detection in rolling element bearings. Mechanical Systems and Signal Processing, 2012. 
[17] ZIMROZ R.: Optymalizacja wyboru szerokości pasma w demodulacji sygnalu do wykrywania uszkodzeń lokalnych w elementach maszyn górniczych, Prace Naukowe Instytutu Górnictwa Politechniki Wrocławskiej. Studia i Materiały, vol. 118, nr 33, s. 151-161, ISSN 0370-0798. 